\title{
Canada's craton: A bottoms-up view
}

Dante Canil, School of Earth and Ocean Sciences, University of Victoria, 3800 Finnerty Road, Victoria V8W 3P6, British Columbia,dcanil@uvic.ca

\section{ABSTRACT}

The origin of mantle lithosphere underlying Archean crustal provinces is most consistent with depletion at low pressures in the spinel facies under degrees of melting higher than observed in modern ocean basins. Depleted sections of the lithosphere created in convergent margin settings were underthrust and stacked to build a thick root with time. Geochronologic and geologic evidence can be interpreted to show that the final formation and amalgamation of the bulk of the "mantle root" occurs $0.5-1$ b.y. later than the age of the lithosphere from which it is comprised. "Silica enrichment" is not ubiquitous in the mantle beneath Archean crustal provinces. Where it does occur, it may be a heterogeneous feature possibly imparted by marine weathering of peridotite on the Archean ocean floor before it was stacked to form a mantle root.

\section{INTRODUCTION}

Cratons are defined as stable portions of the continental plates that have escaped tectonic reworking for long periods (giga-annum [Ga]). Thirty-five Archean crustal provinces are recognized within the cratons of continents today (Bleeker, 2003). The largest mass of lithosphere beneath these cratons underlies the Moho in the mantle. Thus, the long-term strength and stability of a craton must be engendered in the properties of its mantle lithosphere, which may ultimately be tied to the origins of continents themselves.

The purpose of this review is to summarize some thermal, petrological, and geological constraints on the evolution of cratonic lithosphere as sampled by kimberlites in Canada. Canada is centered over a large craton and has the largest proportion of Archean crust in the world exposed at its surface, making it the focus of diamond exploration in the past 15 years. A significant portion of the Lithoprobe program was devoted to the geophysical imaging of lithosphere beneath the craton (Fig. 1). The geophysical surveys in this and other such programs (e.g., DeepProbe, Kaapvaal project, USArray) provide a present-day interpretation of the deep lithosphere but by themselves do not explain its origin and evolution. Mantle rocks sampled as xenoliths provide the only "in place" record of Archean and younger processes beneath cratons, hence providing us with a link between the deep lithosphere, surface geology, and geophysical data (Carlson et al., 2005).

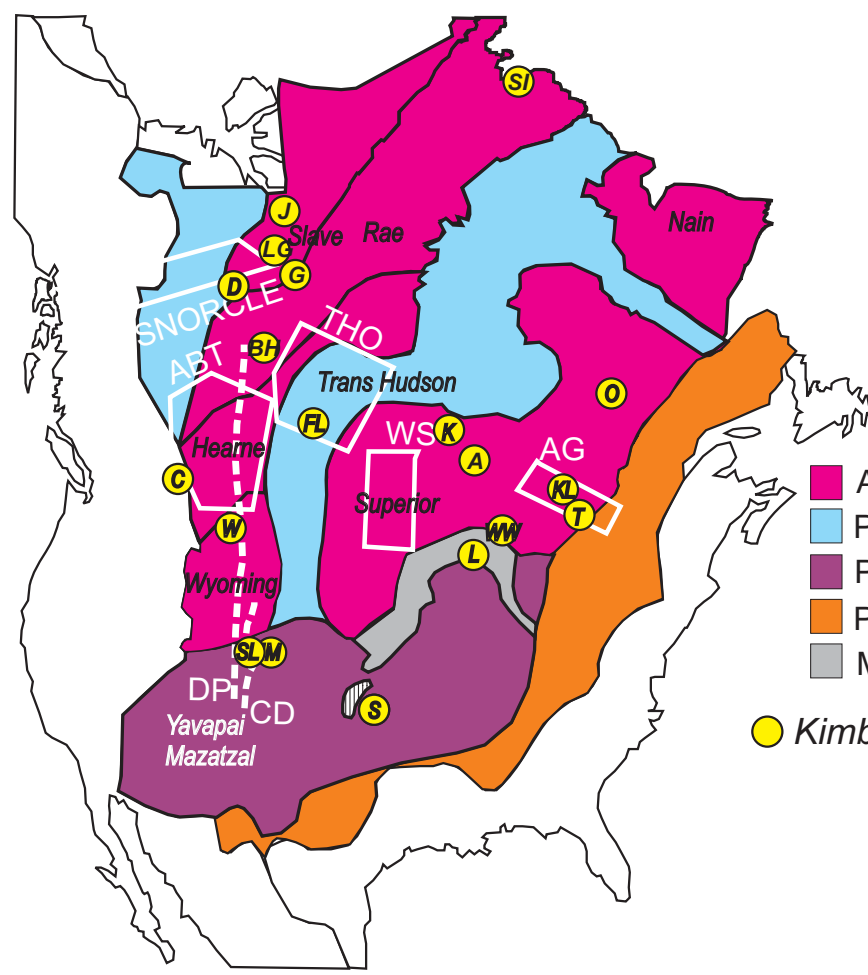

Figure 1. Precambrian basement map of North America stripped of its Phanerozoic sedimentary cover (after Hoffman, 1988, 1990; Ross et al., 1991). Boxes show locations of various geophysical transects within the Lithoprobe program. Also shown are kimberlite fields, clusters, and pipes, clockwise from top: SI-Somerset Island; O-Otish Mountains/Renard;

Archean

Proterozoic (2.0 - $1.85 \mathrm{Ga})$

Proterozoic (1.8 - 1.6 Ga)

Proterozoic (1.3 - $1.0 \mathrm{Ga})$

Mid-Cont. Rift (1.1 Ga)

Kimberlite (pipes or fields) $\mathrm{KL}$-Kirkland lake; T-Timiskaming; WW-Wawa; L-Lake Ellen; S-Stockdale; A-Attawapiskat; K-Kyle Lake; IM-Iron Mountain; SL-State Line; W-Williams; C-Crossing Creek; FL-Fort a la Corne; BH-Buffalo Hills; D-Drybones Bay; G-Gahcho Kue; LG-Lac de Gras; J-Jericho. 


\section{PALEOGEOTHERMS AND THE THERMAL HISTORY OF CRATONS}

The cooling of the earth and the distribution of its heat sources have long been of interest (Pollack and Chapmen, 1977; Verhoogen, 1956) but with few direct constraints. I examine the cooling history of cratons with a focus on the Archean Slave Province in Canada using available heat flow measurements, geochronological data, and pressure-temperature $(P-T)$ data for xenoliths that cover a $300 \mathrm{~km}$ length of the province (Fig. 2). The $P-T$ data are based on analyses from the same electron microprobe laboratory, eliminating interlaboratory inconsistency and enhancing precision.

The $P-T$ arrays of xenoliths from the Gahcho Kue, Grizzly, and Jericho pipes in the Slave Province are identical within error of the thermobarometers applied, despite the fact that these kimberlites vary in age by 500 m.y. (Fig. 3). I fit the $P-T$ arrays to a "steady state" geotherm with input parameters of (1) surface heat flow, heat generation, and crustal thickness measured in the central Slave Province (Mareschal et al., 2004); (2) crustal heat generation of $0.6 \mu \mathrm{Wm}^{-2}$ (Rudnick and Nyblade, 1999; Russell et al., 2001); and (3) an empirical fit of change in thermal conductivity with depth (MacKenzie and Canil, 1999).

The thermal structure of the Slave Province mantle has not changed significantly in the past 500 m.y. over a scale of $\sim 300$ $\mathrm{km}$ (Fig. 3). The uniform thermal structure contrasts with the petrologic structure, which varies vertically and laterally across the province. In plan view, the Slave mantle structure consists of three NE-striking ribbons of lithosphere with different levels of depletion, as deduced by garnet geochemistry (Grütter et al., 1999), that parallel slight changes in the direction of seismic anisotropy (Davis et al., 2003b) (Fig. 2). The vertical distribution of mantle peridotite in the $\sim 180-220$-km-thick lithosphere consists of a shallow, ultradepleted layer underlain by a deeper, more fertile layer (Griffin et al., 1999a; Kopylova and Russell, 2000; Kopylova and Caro, 2004). The ultradepleted layer tapers to the southwest near Drybones Bay, where its base coincides with changes in seismic anisotropy over a narrow interval between 110 and $130 \mathrm{~km}$ depth (Carbno and Canil, 2002). This seismic discontinuity has been interpreted as the remnant of a lithospheric underthrust or "stack" (Bostock, 1998).

Although Slave Province mantle can be considered to be in a thermal steady-state at the time of sampling by kimberlites over the past 550 m.y., this state reveals nothing of when this equilibrium was reached, which, given the thermal time constant for 200-km-thick lithosphere, is 1-2 b.y. (Mareschal and Jaupart, 2006). Furthermore, the paleogeotherm gives no direct information on the mantle heat flow at the end of the Archean when the Slave Province is presumed to have "stabilized." If the lithosphere was to remain strong and stabilize the craton, its initial temperature must have been below the steady-state regime, with basal heat flow the same as today (Mareschal and Jaupart, 2006), a condition made permissible if the lithospheric root formed by accretion of "cold" subducting plates.

\section{AGE OF CRATONIC MANTLE "ROOTS"}

The Re-Os isotopic system has been employed extensively to estimate the age of peridotitic mantle lithosphere (Pearson, 1999). The Re/Os ratio of mantle residue decreases with melt extraction and over time evolves to low ${ }^{187} \mathrm{Os} / 188 \mathrm{Os}$ isotopic ratios. Some measure of the minimum age of the lithosphere can be made from ${ }^{187} \mathrm{Os} /{ }^{188} \mathrm{Os}$ by assuming all Re was lost on melting to produce a "Re depletion age" $\left(T_{R D}\right)$ of a sample.

The $T_{R D}$ for kimberlite-borne mantle xenoliths from the Slave, Wyoming, and North Atlantic (Somerset Island) provinces

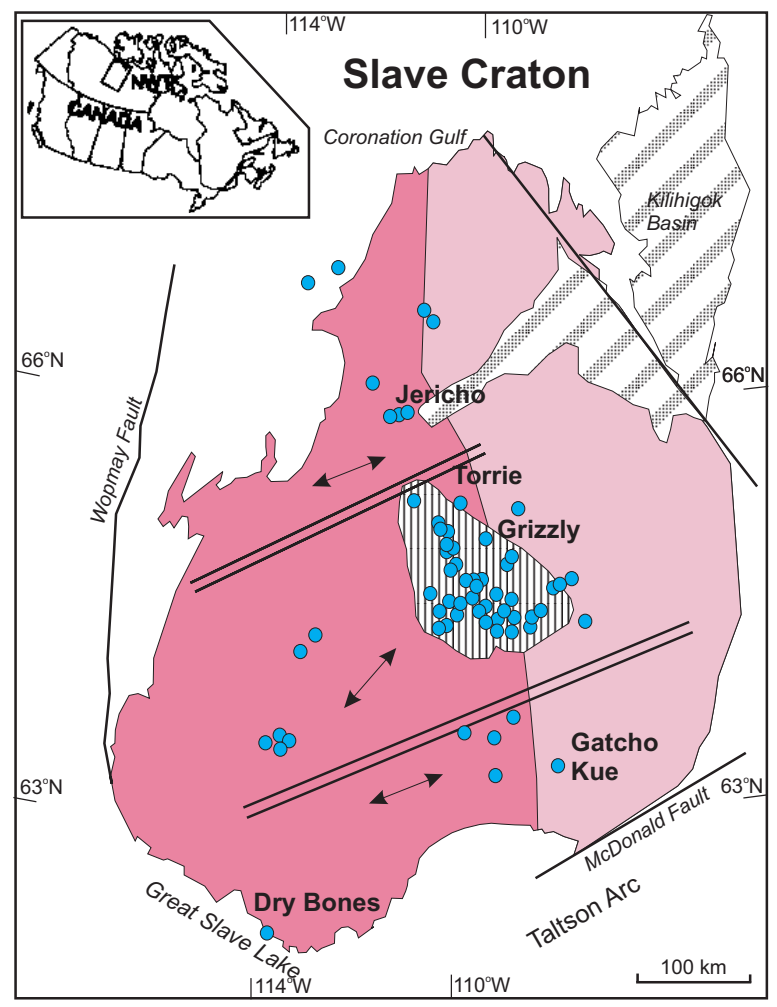

Figure 2. Geological map of the Archean Slave Province (modified after Davis et al., 2003b; Kopylova and Caro, 2004) distinguishing Mesoarchean basement (deeper pink) from more juvenile crust to the east. Also shown are the electrical conductivity anomalies in the central Slave upper mantle (Jones et al., 2001) and northeast-trending mantle domains of varying azimuth of S-wave anisotropy (arrows) in the craton (Davis et al., 2003b; Grütter et al., 1999). Kimberlites (some labeled) are shown as blue dots.
Conductive mantle anomaly

Proterozoic Basin Juvenile Basement Mesoarchean Basement Kimberlite pipes S-wave polarization Mantle Domain Boundary 


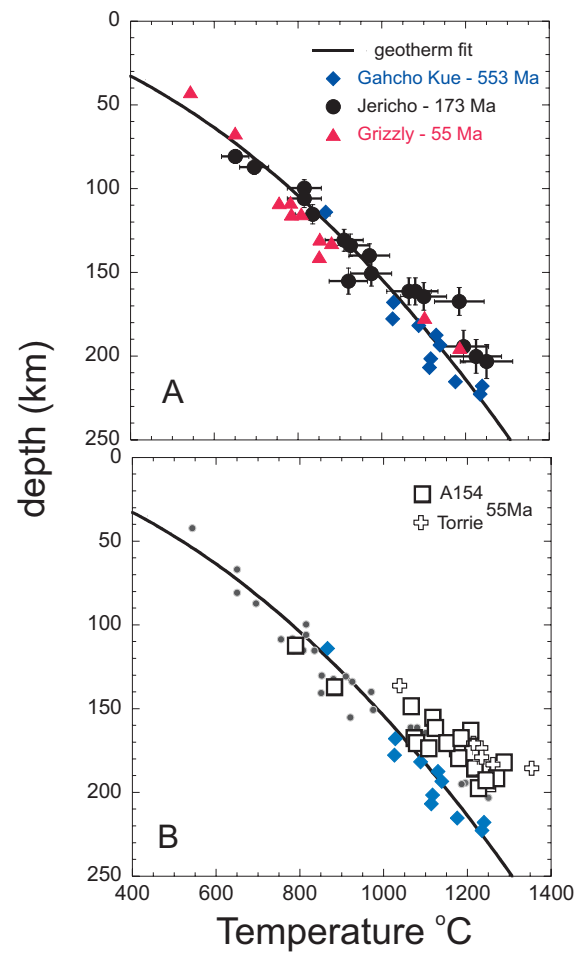

Figure 3. $P$ - $T$ arrays for peridotite xenoliths from (A) three kimberlite pipes labeled in Figure 2, with $\mathrm{U}-\mathrm{Pb}$ ages from 553 to $55 \mathrm{Ma}$ (Heaman et al., 2003) and with analytical data all from the same electron microprobe laboratory (Boyd and Canil, 1997; Kopylova and Caro, 2004; Kopylova et al., 1999). Error bars show uncertainty on temperature and pressure (depth). (B) Same as above compared to $P$ - $T$ data from two younger pipes (Aulbach et al., 2007; MacKenzie and Canil, 1999) which may even show a local "warming" mantle compared to those in (A).

are the same as most other Archean provinces (Fig. 4). These ages established that melt extraction to form cratonic lithosphere is dominantly Archean, with some samples showing Proterozoic and younger modification (Carlson et al., 2005; Pearson, 1999). A similar age of melt extraction emerges from a whole-rock Lu-Hf isochron of peridotites in Somerset Island (Schmidberger et al., 2002).

Mantle lithosphere ages correspond with crustal ages in Archean provinces, leading to the inference that cratonic mantle roots formed and were coupled to their overlying Archean crust within a narrow time frame and have remained there ever since. This scenario poses a paradox. Several late and post-Archean events attributed to heating and/or orogenic activity are recorded in the upper and lower crust of cratons in both the Slave and Superior provinces, as indicated by late- and post-Archean ages of
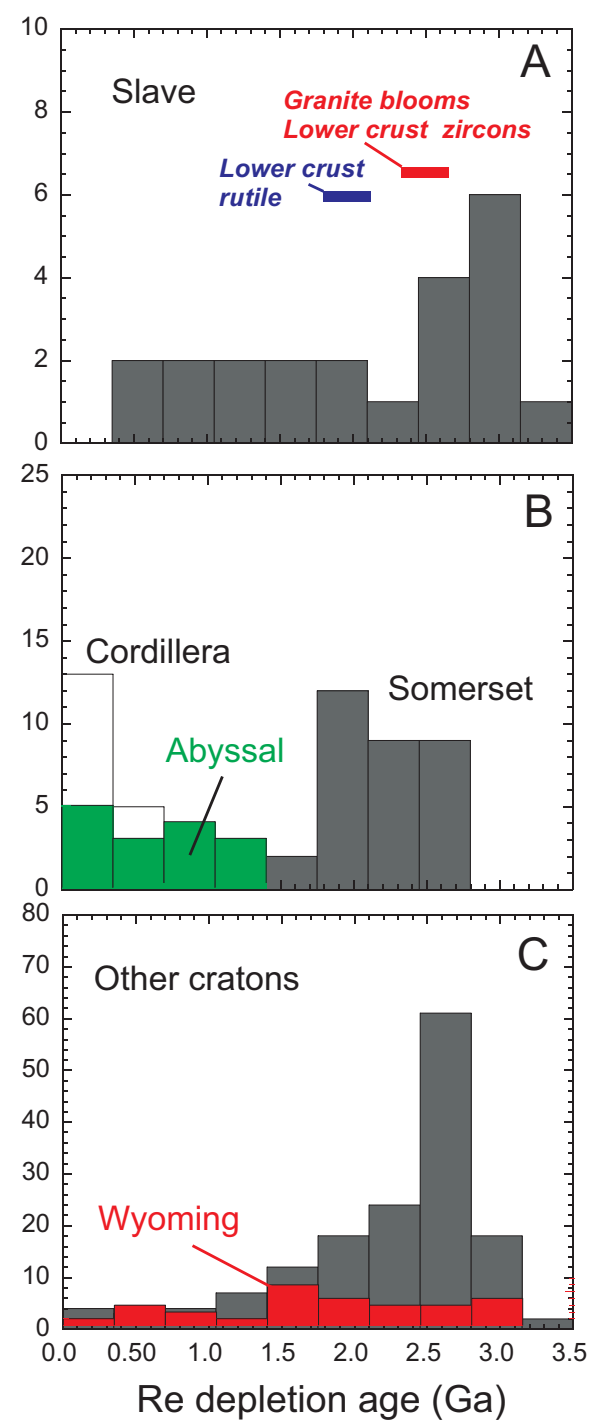

Figure 4. Frequency histograms of Re depletion ages for cratonic xenoliths from (A) Slave Province; (B) Somerset Island, the (off-craton) Canadian Cordillera, and abyssal peridotites; and $(\mathrm{C})$ the Wyoming Province (data from Pearson, 1999; Pearson et al., 2003). Shown for comparison in $(\mathrm{A})$ are $\mathrm{U}-\mathrm{Pb}$ ages for various events recorded in the crust of the Slave Province: metamorphic zircons and rutile in lower crustal granulite xenoliths, late "granite blooms," and Lu-Hf and U-Pb ages of eclogite xenoliths in the Jericho pipe.

(1) metamorphic zircon in kimberlitehosted lower crustal granulite xenoliths (Davis et al., 2003a; Moser and Heaman, 1997); (2) "granite blooms" in greenstone belts (Davis et al., 2003b); and (3) hydrothermal mineralization in lode gold deposits (Fig. 4). These widespread thermal events would be at odds with simultaneous development below a well-established, deep "cold" Archean lithospheric root as recorded by its Re depletion ages. Simple one-dimensional thermal modeling shows that a thermal pulse causing melting and metamorphism in the lower crust to form late granite blooms need not have thermally imprinted the entire craton root (Davis et al., 2003b). Alternatively, a recent geodynamic model proposes that cratonic lithosphere inverted its eclogite-bearing root during the latest Archean, causing melting in its lowermost crust (Percival and Pysklyvec, 2007). Both of the above models hinge on when the "root" was established and stabilized.

There is some reason to recognize the resolution and limitations of the Re-Os model ages for mantle lithosphere. More than half of the Os in mantle peridotites can reside in micron-sized platinum group minerals (PGMs), which have a high-temperature stability and high partition coefficient for platinum group elements (Luguet et al., 2007). The PGMs can remain stable throughout the melting interval and may be recycled into later generations of lithosphere, accounting for the anomalously old Os ages (0.5-1.0 $\mathrm{Ga}$ ) recorded in geologically young lithosphere in modern ocean basins (abyssal peridotites, Fig. 4). Given this attribute of the Re-Os system (Meibom et al., 2002), it is conceivable that the $T_{R D}$ of many cratonic xenolith samples may record the Os in PGMs that have been preserved from prior (Archean) melting events but that were later recycled into younger "roots."

Eclogite xenoliths also call into question purely Archean "root formation." Eclogite xenoliths are interpreted by many to be representative of oceanic basaltic crust now embedded in cratonic mantle roots by lithosphere subduction or stacking (Helmstaedt and Schulze, 1989; Jacob, 2004). The eclogites occur at various depth intervals throughout the Slave province mantle root (Kopylova et al., 1999). Based on Lu-Hf and U-Pb zircon systematics, these eclogites are demonstrably younger than the majority of $T_{R D}$ for mantle peridotites (Fig. 4), but correspond to identical ages of Paleoproterozoic subduction (ca. $2.0 \mathrm{Ga}$ ) recorded in surface geology at the externides of this Archean province (Schmidberger et al., 2007). If Proterozoic eclogite is a component of the root, then "root" formation must be Proterozoic even if Archean peridotite constitutes the 
bulk of the lithosphere. Thus, the age of the "root" formation may be younger than the age of the lithosphere that comprises the root. This hypothesis is consistent with $\mathrm{U}-\mathrm{Pb}$ ages from lower crustal granulite xenoliths, which show that the Slave craton root cooled through the $\mathrm{U}-\mathrm{Pb}$ blocking temperature of metamorphic rutile $\left(\sim 400{ }^{\circ} \mathrm{C}\right)$ to a present-day cratonic geotherm only by ca. $1.8 \mathrm{Ga}$, well after the Archean (Fig. 4). Similarly, 1.9-Ga sedimentary basins on the Slave Province record subsidence on a thinner, root-free thermal lithosphere at that time (Grotzinger and Royden, 1990).

Most intriguing is that the Re-Os ages of sulfides in kimberlite-borne diamonds sampled from the Slave Province, presumably hosted in the lithosphere, are ca. 3.5 Ga (Aulbach et al., 2004; Westerlund et al., 2006) and pre-date the NeoArchean $(2.8-2.55 \mathrm{Ga})$ formation and amalgamation of overlying crust by at least 0.5 b.y. A similar pattern is evident in the Superior Province of Canada (Stachel et al., 2006) and in Kaapvaal of southern Africa (Richardson et al., 2001). In the mantle, sulfide is molten and potentially mobile, and Os has a low closure temperature in this phase (Brenan et al., 2000), calling into question the validity of diamond ages from sulfide and other inclusions (Navon, 1999). Nonetheless, if the ages are taken at face value, they show that the formation of mantle lithosphere predates its development into a craton "root" below Archean crust by 0.5-1.0 Ga.

\section{TECTONIC SETTING FOR CRATONIC LITHOSPHERE}

Mantle lithosphere is a residue of melt extraction from peridotite, which at pressures below $\sim 3$ GPa produces olivine at the expense of all other phases and increases its $\mathrm{Mg} / \mathrm{Fe}$ with depletion. This attribute of the melting process is reflected geochemically in residual peridotites by increasing $\mathrm{Mg} / \mathrm{Si}$ with increasing $\mathrm{Mg} /(\mathrm{Mg}+\mathrm{Fe})$, as exhibited by peridotites sampled in modern ocean basins, ophiolites, orogenic massifs, or continental basalt-hosted xenoliths (Fig. 5). Most cratonic lithosphere is distinct from the latter by being depleted in $\mathrm{Fe}$ (high $\mathrm{Mg} \#$ ) but having variable $\mathrm{Mg} / \mathrm{Si}$ (Figs. 5B and 5C) (Boyd, 1989). The compositional spectrum of low $\mathrm{Fe}$ and high $\mathrm{Si}$ in cratonic peridotites is unattainable by melting of primitive mantle
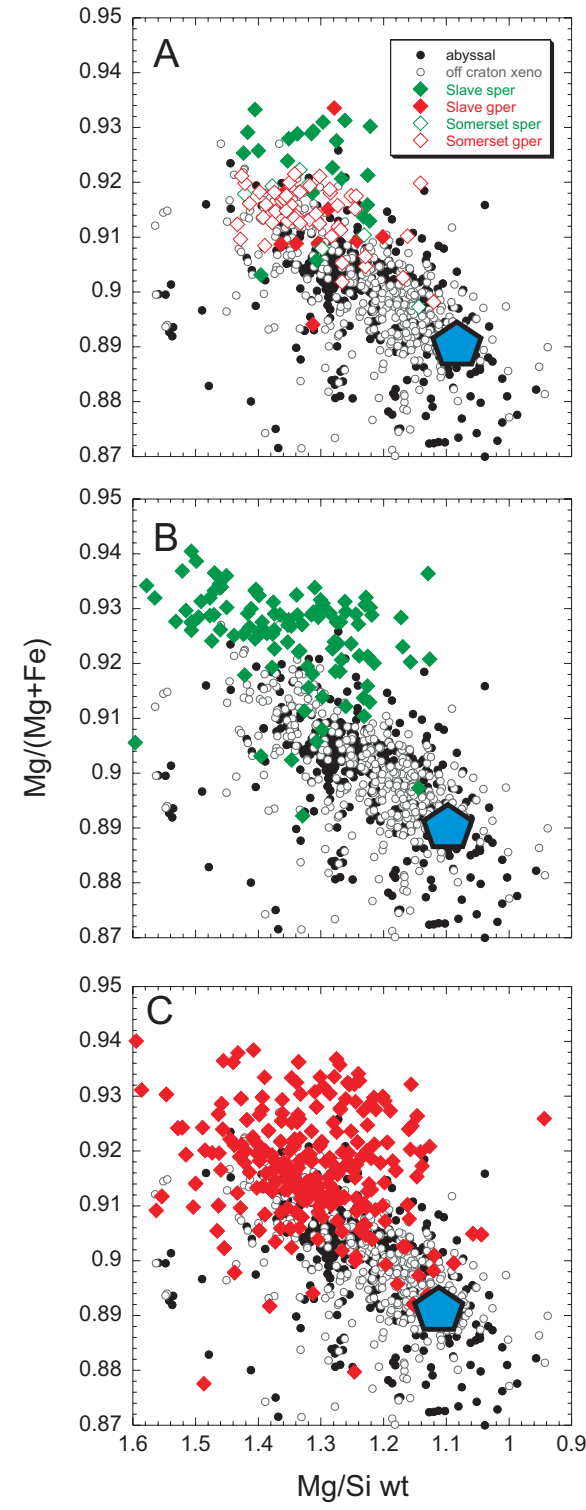

Figure 5. Covariation of $\mathrm{Mg} / \mathrm{Si}$ with $\mathrm{Mg} / \mathrm{Mg}$ $+\mathrm{Fe})(\mathrm{Mg} \#)$ in whole rock analyses of cratonic peridotite xenoliths compiled by the author (Canil, 2004). The large polygon represents primitive upper mantle peridotite (McDonough and Sun, 1995). (A) Off-craton xenoliths and spinel- and garnet-facies xenoliths (sper, gper) from the Slave Province and Somerset Island. (B) Cratonic spinel-facies. (C) Cratonic garnetfacies xenoliths.

peridotite at any pressure (Walter, 2003), but could be explained if they were residues of a more Si-rich and Fe-poor chondritic mantle, which has, since the Archean, escaped sampling during Proterozoic and younger melting processes (Francis, 2003). The trend to higher Si at a given $\mathrm{Mg \#}$ could also be due to a secondary process (Herzberg, 2004; Kelemen et al., 1998).

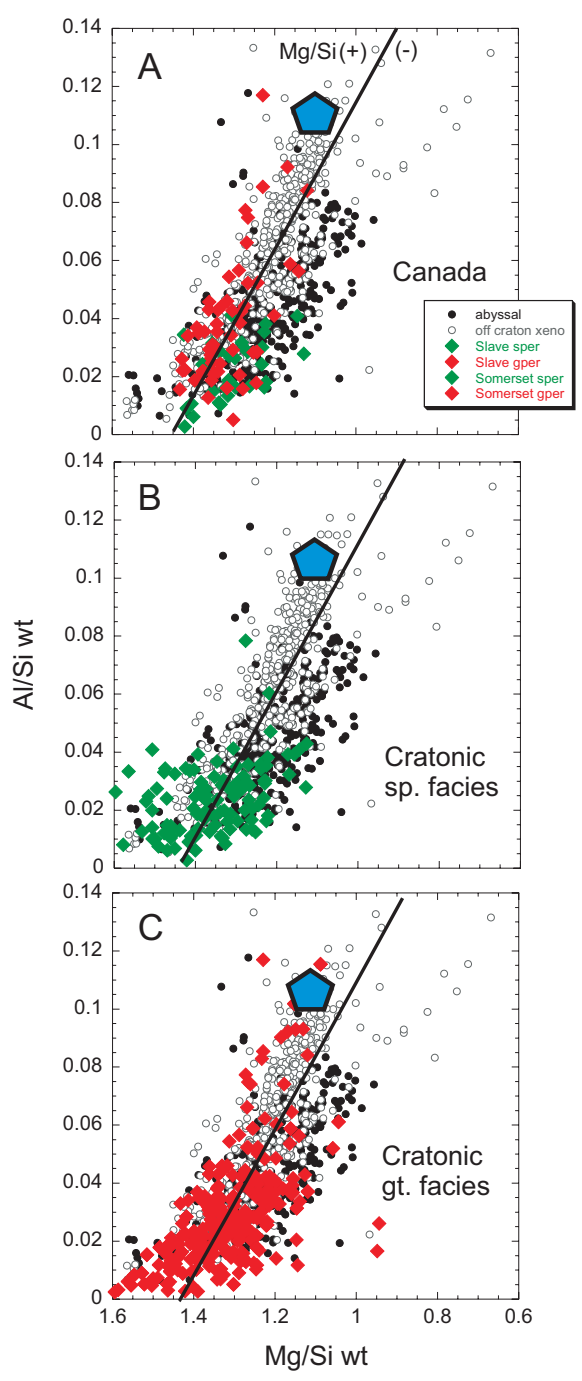

Figure 6. Covariation of $\mathrm{Mg} / \mathrm{Si}$ with $\mathrm{Al} / \mathrm{Si}$ in world xenolith data set as in Figure 5. (A) shows the trend for Canadian xenoliths compared with off-craton and abyssal peridotites. The line for all off-craton xenoliths is fitted by least squares to an equation of $[\mathrm{Mg} / \mathrm{Si}]=1.44(2)-3.66(11)$ [Al/Si] (95\% confidence, $r=0.79)$. Samples to the left or right of this line have a positive or negative " $\Delta \mathrm{Mg} / \mathrm{Si}^{\prime}$ value. The remaining panels show all (B) cratonic spinel-facies and (C) cratonic garnet facies mantle xenoliths.

Global data sets of all types of mantle peridotites show a covariation of $\mathrm{Mg} / \mathrm{Si}$ with $\mathrm{Al} / \mathrm{Si}$ that is a consequence of partial melt extraction (Pearson et al., 2003) and can be fitted to a line: $[\mathrm{Mg} / \mathrm{Si}]=$ $1.440(8)-3.66(11)[\mathrm{Al} / \mathrm{Si}](r=0.79,95 \%$ confidence) (Fig. 6). Samples scatter to each side of that line, having higher or lower $\mathrm{Mg} / \mathrm{Si}$ (hereafter referred to as $\Delta \mathrm{Mg} / \mathrm{Si})$, respectively, at a given degree of depletion $(\mathrm{Al} / \mathrm{Si})$. The $\Delta \mathrm{Mg} / \mathrm{Si}$ of $\mathrm{cra}-$ tonic xenoliths can be compared with off-craton mantle to rigorously examine 

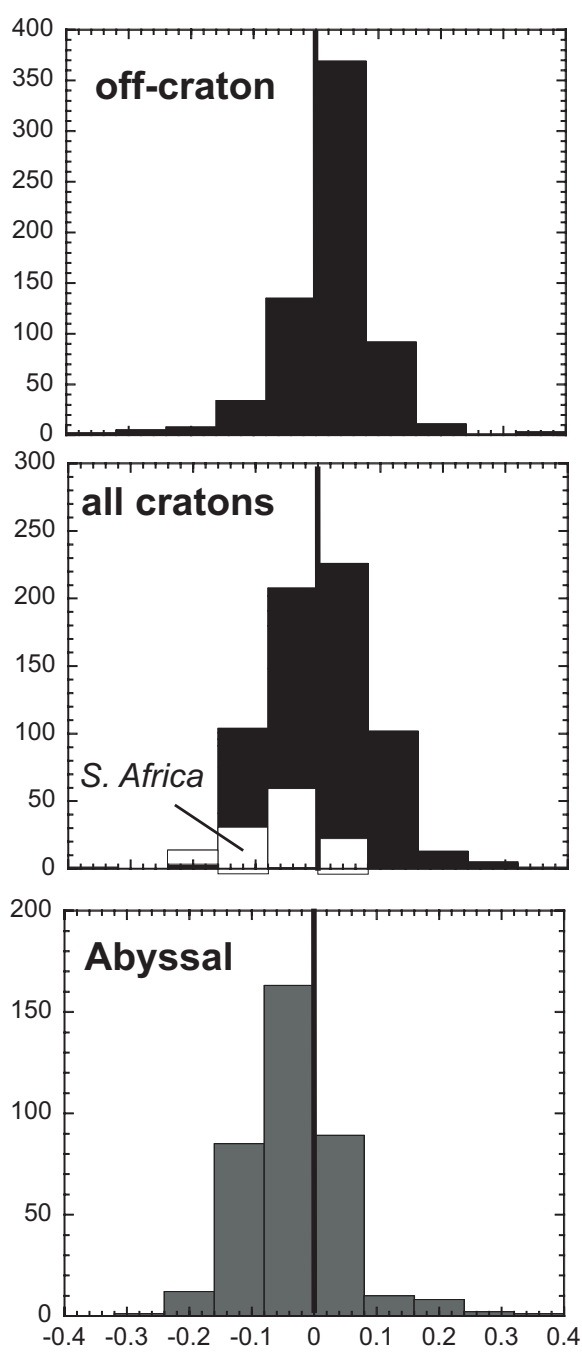
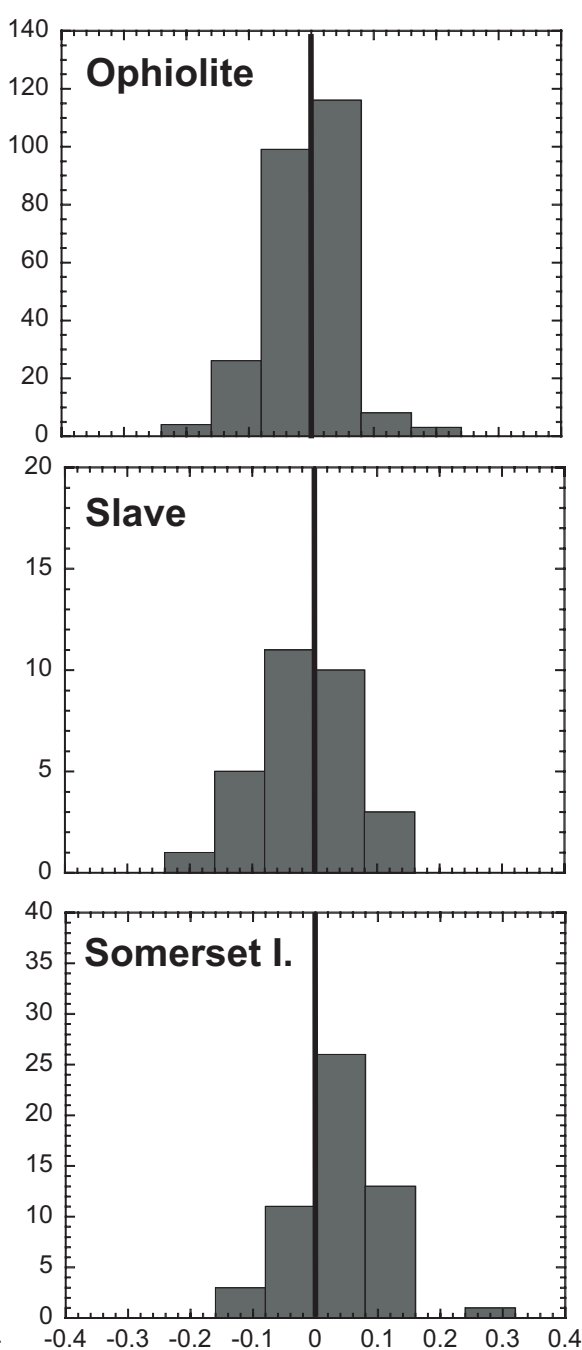

Figure 7. Histograms of $\Delta \mathrm{Mg} / \mathrm{Si}$ for peridotites showing the frequency of Si-enrichment relative to the off-craton array (from Fig. 6) in various mantle peridotite types.

\section{$\Delta \mathrm{Mg} / \mathrm{Si}$}

the ubiquity (or not) of $\mathrm{Si}$ enrichment (low $\mathrm{Mg} / \mathrm{Si}$ ). The $\Delta \mathrm{Mg} / \mathrm{Si}$ for cratonic mantle as a whole is normally distributed about zero, similar to other kinds of mantle lithosphere (Fig. 7). Thus, "Si enrichment" in cratonic mantle is an exception, occurring in a minority of samples. Indeed, the lower $\mathrm{Mg} / \mathrm{Si}$ (or negative $\Delta \mathrm{Mg} / \mathrm{Si}$ ) observed in some cratonic peridotites is prevalent mostly in South Africa (Fig. 7). In modern abyssal peridotites, low $\mathrm{Mg} / \mathrm{Si}$ at a given degree of depletion is a consequence of seafloor exposure and marine weathering (Snow and Dick, 1995). It appears possible that the lower Mg/ $\mathrm{Si}$ (i.e., Si enrichment, negative $\Delta \mathrm{Mg} / \mathrm{Si}$ ) in some cratonic mantle is due to marine weathering, if its protoliths were at one time exposed to Archean seawater and later subducted to form a craton root.

Unlike Si enrichment, Fe depletion in cratonic mantle is ubiquitous (Fig. 5). Given current experimental data, generating the low $\mathrm{Fe}$ in cratonic peridotites from primitive mantle sources can only occur by melting at high pressures ( $>5 \mathrm{GPa}$; Walter, 2003). This has led to the belief that cratonic mantle is a residue of high-pressure melting in plumes and attaches to the craton root vertically by "plume subcretion" (Aulbach et al., 2007; Griffin et al., 1999a). This mode of origin at pressures
$>5 \mathrm{GPa}$ is inconsistent with a number of trends in $\mathrm{Cr}, \mathrm{Al}$, and mildly incompatible elements in peridotite, which preclude extensive melting at pressures greater than $3 \mathrm{GPa}$ (Canil, 2004; Canil and Wei, 1992; Kelemen et al., 1998; Kesson and Ringwood, 1989; Stachel et al., 1998).

If produced at low pressure, low $\mathrm{Fe}$ in cratonic peridotites requires either a source with higher $\mathrm{Mg \#}$ or melting under conditions that greatly change the distribution of Fe from Mg. Because $\mathrm{Fe}^{3+}$ is ten times more incompatible than $\mathrm{Fe}^{2+}$ (Canil et al., 1994), melting at higher oxygen fugacity $\left(f \mathrm{O}_{2}\right)$ results in a residue with higher $\mathrm{Mg} / \mathrm{Fe}$ for a given degree of melting. No experimental studies directly investigate the effect of $\mathrm{fO}_{2}$ on major element systematics $(\mathrm{Mg} / \mathrm{Fe})$ of mantle melting, but this effect can be examined using the behavior of vanadium (V), which is mildly incompatible and redox sensitive (Canil, 2002). The lower $\mathrm{V}$ at a given degree of depletion in many cratonic peridotites could result from melting at higher $f \mathrm{O}_{2}$. If this is correct, then by analogy with modern settings, the mantle now beneath Archean crustal provinces was generated in the upper plate of a convergent margin, consistent with a "stack" origin.

The lack of correlation of Mg\# in olivine with modal olivine also distinguishes cratonic peridotites from Phanerozoic or 
off-craton peridotites (Fig. 5), and the lack of correlation can only occur by melting to near or beyond orthopyroxene exhaustion ( 40\%) (Bernstein et al., 2007). This means the upper spinel facies portion of cratonic lithosphere was originally a nearly dunitic residue. This trend to extremely depleted lithosphere at the shallowest levels in the lithospheric column beneath cratons is evident in xenolith data sets from the Slave Province (Aulbach et al., 2007; Kopylova and Russell, 2000) and is an almost universal observation in mantle columns constructed from kimberlite-hosted garnet xenocryst suites elsewhere in Canada and throughout the world (Canil et al., 2003; Gaul et al., 2000; Griffin et al., 1999b; Scully et al., 2004). The highly depleted shallow levels of mantle lithosphere beneath Archean provinces provide the compositional buoyancy required to support their cratonic roots against removal into the convecting mantle (Jordan, 1975; Lee, 2003; Poudjom Djomani et al., 2001).

\section{SUMMARY}

The weight of thermal, petrologic, and geological evidence points toward an origin for lithosphere beneath Archean provinces in a convergent margin. Most of that lithosphere is Archean in age, but many lines of evidence show that the deep lithosphere beneath these regions did not "stack" or stabilize a "root" until at least 0.5 b.y. later. If so, was Archean crust tectonically emplaced atop the mantle lithosphere in a stack that in North America is more appropriately described as early Proterozoic in age? Why does lithospheric stacking not occur today? Did plate thicknesses and lengths in the Precambrian differ enough from the present-day to engender a more neutral buoyancy, required for shallow subduction and "stacking" (Davies, 1992)? The level of depletion in mantle roots seems the key, but more sluggish plate tectonics proposed for the Archean (Korenaga, 2006) may also be part of the answer. Slower plates and fewer convergent margins with a smaller proportion of early continents may explain the time lag of $0.5-1$ b.y. between lithosphere age and the age of actual mantle "root" or "stabilization." Better chronometry of mantle rocks would help test this idea but is made difficult by their equilibration above the closure temperatures of many isotopic systems.

This challenge is also an opportunity. The cooling rates of the continents and the transient thermal signals therein (Michaut and Jaupart, 2007) have the potential to be understood by the different closure properties for different isotopic systems in mantle minerals from cratonic xenoliths (Bedini et al., 2004). Further correlation of geophysical and geological observations to the petrology and geochronology of xenoliths in cratons densely sampled by kimberlites can address these questions.

\section{ACKNOWLEDGMENTS}

I give credit to R. Clowes for his energy and leadership in Canada's Lithoprobe program and thank M. Bostock, J. Percival, and S. Johnston for their reviews. Research summarized here was supported in part by Lithoprobe and Discovery Grants from the Natural Sciences and Engineering Research Council of Canada.

\section{REFERENCES CITED}

Aulbach, S., Griffin, W.L., Pearson, N.J., O'Reilly, S.Y., Kivi, K., and Doyle, B.J., 2004, Mantle formation and evolution, Slave Craton: constraints from HSE abundances and Re-Os isotope systematics of sulfide inclusions in mantle xenocrysts: Chemical Geology, v. 208, p. 61-88, doi: 10.1016/j.chemgeo.2004.04.006.

Aulbach, S., Griffin, W.L., Pearson, N.J., O'Reilly, S.Y., and Doyle, B.J., 2007, Lithosphere formation in the central Slave Craton (Canada): Plume subcretion or lithosphere accretion?: Contributions to Mineralogy and Petrology, v. 154, no. 4, doi: 10.1007/s00410-007-0200-1.

Bedini, R.-M., Blichert-Toft, J., Boyet, M., and Albarede, F., 2004, Isotopic constraints on the cooling of the continental lithosphere: Earth and Planetary Science Letters, v. 223, p. 99-111, doi: 10.1016/j.epsl.2004.04.012.

Bernstein, S., Kelemen, P.B., and Hanghoj, K., 2007, Consistent olivine Mg\# in cratonic mantle reflects Archean mantle melting to the exhaustion of orthopyroxene: Geology, v. 35, p. 459-462, doi: 10.1130/G23336A.1.

Bleeker, W., 2003, The late Archean record: puzzle in ca. 35 pieces: Lithos, v. 71, p. 99-134, doi: 10.1016/j.lithos.2003.07.003.

Bostock, M.G., 1998, Mantle stratigraphy and evolution of the Slave province: Journal of Geophysical Research, v. 103, p. 21,183-21,200, doi: 10.1029/98JB01069.

Boyd, F.R., 1989, Compositional distinction between oceanic and cratonic lithosphere: Earth and Planetary Science Letters, v. 96, p. 15-26, doi: 10.1016/0012-821X(89)90120-9.

Boyd, F.R., and Canil, D., 1997, Peridotite xenoliths from the Slave craton, NWT: LPI Contribution 921, p. 34.

Brenan, J.M., Cherniak, D.J., and Rose, L.A., 2000, Diffusion of osmium in pyrrhotite and pyrite: Implications for closure of the Re-Os isotopic system: Earth and Planetary Science Letters, v. 180, p. 399-413, doi: 10.1016/S0012821X(00)00165-5.

Canil, D., 2002, Vanadium in peridotites, mantle redox and tectonic environments: Archean to present: Earth and Planetary Science Letters, v. 195, p. 75-90, doi: 10.1016/S0012-821X(01)00582-9.

Canil, D., 2004, Mildly incompatible elements in peridotites and the origins of mantle lithosphere: Lithos, v. 77, p. 375-393, doi: 10.1016/j.lithos.2004.04.014.

Canil, D., and Wei, K., 1992, Constraints on the origin of mantle-derived low Ca garnets: Contributions to Mineralogy and Petrology, v. 109, p. 421-430, doi: 10.1007/BF00306546.

Canil, D., O'Neill, H.S.C., Pearson, D.G., Rudnick, R.L., McDonough, W.F., and Carswell, D.A., 1994, Ferric iron in peridotites and mantle oxidation states: Earth and Planetary Science Letters, v. 123, p. 205-220, doi: 10.1016/0012-821X(94)90268-2.

Canil, D., Schulze, D.J., Hearn, B.C.J., Hall, D.C., and Milliken, S.M., 2003 Lithospheric roots beneath western Laurentia: The geochemical signal in mantle garnets: Canadian Journal of Earth Sciences, v. 40, p. 1027-1051, doi: 10.1139/e03-003.

Carbno, G.B., and Canil, D., 2002, Mantle structure beneath the southwest Slave craton, Canada: Constraints from garnet geochemistry in the Drybones Bay kimberlite: Journal of Petrology, v. 43, p. 129-142, doi: 10.1093/petrology/43.1.129.

Carlson, R.W., Pearson, D.G., and James, D.E., 2005, Physical, chemical and chronological characteristics of continental mantle: Reviews in Geophysics, v. 43, RG1001, doi: 10.1029/2004RG000156.

Davies, G., 1992, On the emergence of plate tectonics: Geology, v. 20, p. 963-966, doi: 10.1130/0091-7613(1992)020<0963:OTEOPT>2.3.CO;2

Davis, W.J., Canil, D., MacKenzie, J.M., and Carbno, G.B., 2003a, Petrology and $\mathrm{U}-\mathrm{Pb}$ geochronology of lower crustal xenoliths and the development of a craton, Slave Province, Canada: Lithos, v. 71, p. 541-573, doi: 10.1016/ S0024-4937(03)00130-0.

Davis, W.J., Jones, A.G., Bleeker, W., and Grutter, H., 2003b, Lithosphere development in the Slave craton: a linked crustal and mantle perspective: Lithos, v. 71, p. 575-590, doi: 10.1016/S0024-4937(03)00131-2.

Francis, D., 2003, Cratonic mantle roots, remnants of a more chondritic Archean mantle?: Lithos, v. 71, p. 135-152, doi: 10.1016/S0024-4937(03)00110-5.

Gaul, O.F., Griffin, W.L., O'Reilly, S.Y., and Pearson, N.J., 2000, Mapping olivine composition in the lithospheric mantle: Earth and Planetary Science Letters, v. 182, p. 223-235, doi: 10.1016/S0012-821X(00)00243-0.

Griffin, W.L., Doyle, B.J., Ryan, C.G., Pearson, N.J., O'Reilly, S., Davies, R., Kivi, K., van Achterbergh, E., and Natapov, L., 1999a, Layered mantle lithosphere in the Lac de Gras area, Slave craton: Composition, structure and origin: Journal of Petrology, v. 40, p. 705-727, doi: 10.1093/petrology/40.5.705.

Griffin, W.L., Fisher, N.I., Friedman, J., Ryan, C.G., and O'Reilly, S.Y., 1999b, Cr-pyrope garnets in the lithospheric mantle. I. Compositional systematics and relations to tectonic setting: Journal of Petrology, v. 40, p. 679-704, doi: 10.1093/petrology/40.5.679.

Grotzinger, J., and Royden, L., 1990, Elastic strength of the Slave craton at 1.9 Gyr and implications for the thermal evolution of the continents: Nature, v. 347, p. 64-66, doi: 10.1038/347064a0.

Grütter, H.S., Apter, D.B., and Kong, J., 1999, Crust-mantle coupling: evidence from mantle-derived xenocrystic garnets, in Gurney, J.J., Gurney, J.L., Pascoe, M.D., and Richardson, S.H., eds., Proceedings of the 7th International Kimberlite Conference, Volume 1: South Africa, p. 307-313.

Heaman, L.M., Kjarsgaard, B.A., and Creaser, R.A., 2003, The timing of kimberlite magmatism in North America: Implications for global kimberlite genesis and diamond exploration: Lithos, v. 71, p. 153-184, doi: 10.1016/ j.lithos.2003.07.005.

Helmstaedt, H., and Schulze, D.J., 1989, Southern African kimberlites and their mantle sample: Implications for the Archaean tectonics and lithosphere evolution: Geological Society of Australia Special Publication 14, p. 358-368. 
Herzberg, C., 2004, Geodynamic information in peridotite petrology: Journal of Petrology, v. 45, p. 2507-2530, doi: 10.1093/petrology/egh039.

Hoffman, P.F., 1988, United Plates of America, the birth of a craton: Early Proterozoic assembly and growth of Laurentia: Annual Review of Earth and Planetary Sciences, v. 16, p. 543-603, doi: 10.1146/annurev.ea.16.050188.002551.

Hoffman, P.F., 1990, Geological constraints on the origin of the mantle root beneath the Canadian shield: Philosophical Transactions of the Royal Society of London, Series B, Biological Sciences, v. 331, p. 523-532, doi: 10.1098/ rsta. 1990.0087.

Jacob, D., 2004, Nature and origin of eclogite xenoliths from kimberlites: Lithos, v. 77, p. 295-316, doi: 10.1016/j.lithos.2004.03.038.

Jones, A.G., Ferguson, I.J., Chave, A.D., Evans, R.L., and McNeice, G.W., 2001 Electric lithosphere of the Slave craton: Geology, v. 29, p. 423-426, doi: 10 1130/0091-7613(2001)029<0423:ELOTSC >2.0.CO;2.

Jordan, T.H., 1975, The continental tectosphere: Reviews in Geophysics, v. 13, no. 3 p. 1-12, doi: 10.1029/RG013i003p00001.

Kelemen, P.B., Hart, S.R., and Bernstein, S., 1998, Silica enrichment in the continental upper mantle via melt/rock reaction: Earth and Planetary Science Letters, v. 164, p. 387-406, doi: 10.1016/S0012-821X(98)00233-7.

Kesson, S.E., and Ringwood, A.E., 1989, Slab-mantle interactions 2. The formation of diamonds: Chemical Geology, v. 78, p. 97-118, doi: 10.1016/00092541(89)90110-1.

Kopylova, M.G., and Caro, G., 2004, Mantle xenoliths from the southeastern Slave Craton: Evidence for chemical zonation in a thick, cold lithosphere: Journal of Petrology, v. 45, p. 1045-1067, doi: 10.1093/petrology/egh003.

Kopylova, M., and Russell, J.K., 2000, Chemical stratification of cratonic lithosphere: Constraints from the northern Slave craton, Canada: Earth and Planetary Science Letters, v. 181, p. 71-87, doi: 10.1016/S0012-821X(00)00187-4.

Kopylova, M.G., Russell, J.K., and Cookenboo, H., 1999, Petrology of peridotite and pyroxenite xenoliths from the Jericho kimberlite: Implications for the thermal state of the mantle beneath the Slave craton: Journal of Petrology, v. 40, p. 79-104, doi: 10.1093/petrology/40.1.79.

Korenaga, J., 2006, Archean geodynamics and the thermal evolution of the earth, in Benn, K., Mareschal, J.C., and Condie, K.C., eds., Archean Geodynamics and Environments: Washington, D.C., American Geophysical Union, Geophysical Monograph 164, p. 7-33.

Lee, C.T.A., 2003, Compositional variation of density and seismic velocities in natural peridotites at STP conditions: Implications for seismic imaging of compositional heterogeneities in the upper mantle: Journal of Geophysical Research, v. 108, B9, 2441, doi: 10.1029/2003JB002413.

Luguet, A., Shirey, S.B., Lorand, J.-P., Horan, M., and Carlson, R.W., 2007, Residual platinum group minerals from highly depleted harzburgites of the Lherz massif (France) and their role in HSE fractionation in the mantle: Geochimica et Cosmochimica Acta, v. 71, p. 3082-3097, doi: 10.1016/j.gca.2007.04.011.

MacKenzie, J.M., and Canil, D., 1999, Composition and thermal evolution of cratonic mantle beneath the central Archean Slave Province, NWT, Canada: Contributions to Mineralogy and Petrology, v. 134, p. 313-324, doi: 10.1007/ s004100050487.

Mareschal, J.C., and Jaupart, C., 2006, Archean thermal regime and stabilization of the cratons, in Benn, K., Mareschal, J., and Condie, K.C., eds., Archean Geodynamics and Environments, Volume Monograph 164: Washington, D.C., American Geophysical Union, p. 61-73.

Mareschal, J.C., Nyblade, A., Perry, H.K.C., Jaupart, C., and Bienfait, G., 2004, Heat flow and deep lithospheric thermal structure at Lac de Gras, Slave Province, Canada: Geophysical Research Letters, v. 31, doi: 10.1029/2004GL020133.

McDonough, W.F., and Sun, S.S., 1995, The composition of the earth: Chemical Geology, v. 120, p. 223-253, doi: 10.1016/0009-2541(94)00140-4.

Meibom, A., Sleep, N.H., Chamberlain, C.P., Coleman, R.G., Frei, R., Hren, M.T., and Wooden, J.L., 2002, Re-Os isotopic evidence for long-lived heterogeneity and equilibration processes in the Earth's upper mantle: Nature, v. 419, p. 705-707, doi: 10.1038/nature01067.

Michaut, C., and Jaupart, C., 2007, Secular cooling and thermal structure of continental lithosphere: Earth and Planetary Science Letters, v. 257, p. 83-96, doi: 10.1016/j.epsl.2007.02.019.

Moser, D.E., and Heaman, L.M., 1997, Proterozoic zircon growth in Archean lower crustal xenoliths, southern Superior craton-a consequence of Matachewan ocean opening: Contributions to Mineralogy and Petrology, v. 128, p. 164-175, doi: $10.1007 / \mathrm{s} 004100050301$
Navon, O., 1999, Diamond formation in the Earth's mantle, in Gurney, J.J., Gurney, J.L., Mascoe, M.D., and Richardson, S.H., eds., The P.H. Nixon Volume: Proceedings of the VII International Kimberlite Conference: Cape Town, Red Roof Design, p. 584-604.

Pearson, D.G., 1999, The age of continental roots: Lithos, v. 48, p. 171-194, doi: 10.1016/S0024-4937(99)00026-2.

Pearson, D.G., Canil, D., and Shirey, S.B., 2003, Mantle samples included in volcanic rocks: xenoliths and diamonds, in Carlson, R.W., ed., Treatise in Geochemistry: Amsterdam, Elsevier, v. 2, p. 171-276

Percival, J.A., and Pysklyvec, R.N., 2007, Are Archean lithospheric keels inverted?: Earth and Planetary Science Letters, v. 254, p. 393-403, doi: 10.1016/ j.epsl.2006.11.047.

Pollack, H.N., and Chapmen, D.S., 1977, On the regional variation of heat flow, geotherms and lithospheric thickness: Tectonophysics, v. 38, p. 279-296, doi: 10.1016/0040-1951(77)90215-3

Poudjom Djomani, Y.H., O'Reilly, S.Y., Griffin, W.L., and Morgan, P., 2001, The density structure of subcontinental lithosphere through time: Earth and Planetary Science Letters, v. 184, p. 605-621, doi: 10.1016/S0012-821X(00)00362-9.

Richardson, S.R., Shirey, S.B., Harris, J.W., and Carlson, R.W., 2001, Archean subduction recorded by Re-Os isotopes in eclogitic sulfide inclusions in Kimberley diamonds: Earth and Planetary Science Letters, v. 191, p. 257-266, doi: 10.1016/ S0012-821X(01)00419-8.

Ross, G.M., Parrish, R.R., Villeneuve, M.E., and Bowring, S.A., 1991, Geophysics and geochronology of the crystalline basement of the Alberta Basin, western Canada: Canadian Journal of Earth Sciences, v. 28, p. 512-522.

Rudnick, R.L., and Nyblade, A.A., 1999, The thickness and heat production of Archean lithosphere: constraints from xenolith thermobarometry and surface heat flow, in Fei, Y., Bertka, C., and Mysen, B.O., eds., Mantle Petrology: Field Observations and High Pressure Experimentation: A Tribute to Francis R. (Joe) Boyd: Geochemical Society, v. 5, p. 3-12.

Russell, J.K., Dipple, G.M., and Kopylova, M.G., 2001, Heat production and heat flow in the mantle lithosphere, Slave craton, Canada: Physics of the Earth and Planetary Interiors, v. 123, p. 27-44, doi: 10.1016/S0031-9201(00)00201-6.

Schmidberger, S.S., Simonetti, A., Francis, D., and Gariepy, C., 2002, Probing Archean lithosphere using the $\mathrm{Lu}-\mathrm{Hf}$ isotope systematics of peridotite xenoliths from Somerset Island kimberlites, Canada: Earth and Planetary Science Letters, v. 197, p. 245-259, doi: 10.1016/S0012-821X(02)00491-0.

Schmidberger, S.S., Simonetti, A., Heaman, L.M., Creaser, R.A., and Whiteford, S., 2007, Lu-Hf, in situ Sr and Pb isotope and trace element systematics for mantle eclogites from the Diavik diamond mine: Evidence for Paleoproterozoic subduction beneath the Slave craton: Earth and Planetary Science Letters, v. 254, p. 55-68, doi: 10.1016/j.epsl.2006.11.020.

Scully, K., Canil, D., and Schulze, D.J., 2004, The lithospheric mantle of the Archean Superior Province as imaged by garnet xenocryst geochemistry: Chemical Geology, v. 207, p. 189-221, doi: 10.1016/j.chemgeo.2004.03.001.

Snow, J.E., and Dick, H.J.B., 1995, Pervasive magnesium loss by marine weathering of peridotite: Geochimica et Cosmochimica Acta, v. 59, p. 4219-4235, doi: 10.1016/0016-7037(95)00239-V.

Stachel, T., Viljoen, K.S., Brey, G., and Harris, J.W., 1998, Metasomatic processes in Iherzolitic and harzburgitic domains of diamondiferous lithospheric mantle: REE in garnets from xenoliths and inclusions in diamonds: Earth and Planetary Science Letters, v. 159, p. 1-12, doi: 10.1016/S0012-821X(98)00064-8.

Stachel, T., Banas, A., Muehlenbachs, K., Kurszlaukis, S., and Walker, E.C., 2006, Archean diamonds from Wawa (Canada): Samples from deep cratonic roots predating cratonization of the Superior Province: Contributions to Mineralogy and Petrology, v. 151, p. 737-750, doi: 10.1007/s00410-006-0090-7.

Verhoogen, J., 1956, Temperatures within the earth: Physics and Chemistry of the Earth v. 1, p. 17-43, doi: 10.1016/0079-1946(56)90004-0.

Walter, M.J., 2003, Melt extraction and compositional variability in mantle lithosphere, in Carlson, R.W., ed., The Mantle and Core: Amsterdam, Elsevier, Treatise on Geochemistry, v. 2, p. 363-394.

Westerlund, K.J., Shirey, S.B., Richardson, S.H., Carlson, R.W., Gurney, J.J., and Harris, J.W., 2006, A subduction wedge origin for Paleoarchean peridotitic diamonds and harzburgites from the Panda kimberlites, Slave craton: evidence from Re-Os isotope systematics: Contributions to Mineralogy and Petrology, v. 152, p. 275-294, doi: 10.1007/s00410-006-0101-8.

Manuscript received 18 December 2007; accepted 29 February 2008. $<$

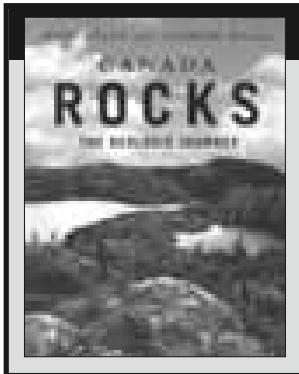

CANADA ROCKS THE GEOLOGIC JOURNEY

WWW.FITZHENRY.CA

GROUNDBREAKING WORK! A marvelous portrait of the incredible "construction project" that gave shape to the continents, mountains, and oceans of planet Earth and created the world's second largest country.

Nick Eyles * Andrew Miall * ISBN 1-55041-8602* Price $\$ 60 * 8.5 \times 11 * 500$ pages * Full-color throughout

Fitzhenry \& Whiteside * 1-800-387-9776 ext $2087 *$ hdoll@fitzhenry.ca

ALSO AVAILABLE FROM FITZHENRY \& WHITESIDE: ONTARIO ROCKS AND TORONTO ROCKS 